\title{
DIRECTIONS OF FORMATION OF HUMANISTIC VALUES IN HIGHER EDUCATION INSTITUTIONS: PROBLEMS AND PERSPECTIVES
}

\author{
INSTRUCÕES PARA A FORMAÇÃO DE VALORES HUMANÍSTICOS NAS \\ INSTITUIÇÕES DE ENSINO SUPERIOR: PROBLEMAS E PERSPECTIVAS
}

\author{
DIRECCIONES DE FORMACIÓN DE VALORES HUMANÍSTICOS EN SUPERIOR \\ INSTITUCIONES EDUCATIVAS: PROBLEMAS Y PERSPECTIVAS
}

Matanat JABBARLI ${ }^{1}$

\begin{abstract}
The article analyzes the directions of the formation of humanistic values in higher education institutions. The results of the study showed that students have a high attitude to humanistic values, regardless of the level of self-affirmation and self-esteem. The main mechanisms of formation of humanistic values in students depend on the provocative features of social values, which occupy a dominant place in the hierarchy of values and professional self-confidence, which reflects the integrated qualities of the individual. It was found that there is a positive correlation between humanistic qualities and personal qualities and academic achievements. There is an important connection between self-awareness, self-esteem, selfassertion, and a social ideal that reflects humanistic qualities in students. It can be concluded that in order to develop humanistic values, it is necessary to develop socially important values and personality traits. Here it is necessary to consider the cognitive needs, opportunities for self-affirmation, as well as learning achievements.
\end{abstract}

KEYWORDS: Higher education institutions. Humanistic values. Students. Main directions. Perspectives in education.

RESUMO: O artigo analisa os rumos da formação de valores humanísticos nas instituições de ensino superior. Os resultados do estudo mostraram que os alunos apresentam elevada atitude em relação aos valores humanísticos, independentemente do nível de autoafirmação $e$ autoestima. Os principais mecanismos de formação de valores humanísticos nos alunos dependem das características provocativas dos valores sociais, que ocupam um lugar dominante na hierarquia de valores e na autoconfiança profissional, refletindo as qualidades integradas do indivíduo. Verificou-se que existe uma correlação positiva entre qualidades humanísticas e qualidades pessoais e realizações acadêmicas. Existe uma ligação importante entre autoconsciência, autoestima, autoafirmação e um ideal social que reflete qualidades humanísticas nos alunos. Pode-se concluir que, para desenvolver valores humanísticos, é necessário desenvolver valores e traços de personalidade socialmente importantes. Aqui é necessário levar em consideração as necessidades cognitivas, as oportunidades de autoafirmação, bem como as conquistas de aprendizagem.

PALAVRAS-CHAVE: Instituições de ensino superior. Valores humanísticos. Alunos. Principais instruções. Perspectivas em educação.

${ }^{1}$ Odlar Yurdu University (OYU), Baku - Azerbaijan. Doctoral student. ORCID: https://orcid.org/0000-00024641-9865. E-mail: matanatjabbarli@gmail.com

RPGE- Revista on line de Política e Gestão Educacional, Araraquara, v. 25, n. esp. 3, p. 1617-1628, Sep. 2021. e-ISSN: 1519-9029 
RESUMEN: El artículo analiza las direcciones de la formación de valores humanistas en las instituciones de educación superior. Los resultados del estudio mostraron que los estudiantes tienen una alta actitud hacia los valores humanistas, independientemente del nivel de autoafirmación y autoestima. Los principales mecanismos de formación de los valores humanistas en los estudiantes dependen de los rasgos provocadores de los valores sociales, que ocupan un lugar dominante en la jerarquía de valores y la autoconfianza profesional, que refleja las cualidades integradas del individuo. Se encontró que existe una correlación positiva entre cualidades humanísticas y cualidades personales y logros académicos. Existe una conexión importante entre la autoconciencia, la autoestima, la autoafirmación y un ideal social que refleja cualidades humanistas en los estudiantes. Se puede concluir que para desarrollar valores humanistas, es necesario desarrollar valores socialmente importantes y rasgos de personalidad. Aquí es necesario tener en cuenta las necesidades cognitivas, las oportunidades de autoafirmación, así como los logros de aprendizaje.

PALABRAS CLAVE: Instituciones de educación superior. Valores humanistas. Estudiantes. Direcciones principales. Perspectivas en la educación.

\section{Introduction}

The socio-political, scientific-cultural, social-economic, spiritual and psychological processes taking place in the era of modern globalization especially the integration of cultures, have a comprehensive impact on students' socio-political relations, their perceptions and value systems about themselves. A new system of values is being formed. This system of values includes not only positive values, but also negative ones. It should be noted that negative values not only change the direction of students' political views, their field of motivations and demands but also cause serious changes in their behavior and attitude to humanistic values. At this time, there are contradictions in the national self-consciousness of students. Of course, Azerbaijan is a multicultural country and is an example in terms of tolerance and various forms of humanism. In order to prevent the degradation of tolerance and humanistic thinking, first of all, it is required to protect students from foreign values, to further develop humanistic values. On the other hand, focusing on the spiritual and psychological state of the individual, changing attitudes towards people, cosmopolitan ideas introduce the formation of humanistic values as an important task. The mega-tendencies observed in the integration process are based on more a humanistic approach, and these tendencies cover all spheres of the world, the sphere of human relations, including the sphere of education. Nowadays, the formation of a personality with humanistic values is a main requirement.

The processes taking place in the world, especially the integration of cultures, have a comprehensive impact on youth's mastery of the "value system". As part of these processes, serious work is being done in this area in our Republic, many measures promoting humanism, 
including world-class events with multiculturalism are taking place. The purpose of such events is the formation of humanistic values, multicultural thinking, tolerance in youth and the presentation of existing traditions to the world through the example of the Azerbaijani people. In this regard, the formation of humanistic values in young people is very topical issue that responds to the process of integration into the world and its challenges.

\section{Methodology}

According to our research, observation, interviews, questionnaires, test methods, $\mathrm{M}$. Rokich's "Value Survey" (ROKEACH, 1968), Sh. Schwartz's "Value Survey" (SCHWARTS, 2010), "Self-esteem Scale" and E. Shostrom's SAT (Self-actualization methodology) methods (SHOSTROM, 2003) were used. In addition, several questionnaires were used to study the role of the media and the process of self-awareness in the formation of humanistic values. The study was conducted among 160 students of Odlar Yurdu University and Azerbaijan State Pedagogical University to determine the methods of development, the manifestations of the psychological features of the formation of humanistic values in Azerbaijani youth. The same number of students ( 80 people) from both universities was involved in the study.

\section{Literature review}

The orientations for the formation of humanistic values in the requirements of higher education institutions are reflected in different approaches. The roots of humanistic values come directly from humanistic psychology and were derived from the methodological concept it defines. Humanistic values are not only human values, but also one of the most important values accepted by mankind. According to most researchers' thoughts, the concept of value is "a large box in which various, often obscure, things are stored" (MASLOW, 2018). Modern research draws attention to special recommendations for the formation of humanistic values in educational institutions. This includes the constructivist approach, the cognitive approach, and the gestational approach.

Creating cognitive contradictions in training, contextual teaching and learning using cognitive recommendations, as well as improving professional development for teachers using original assessment, gestalt approach are the main conditions for the inclusion of humanistic elements in the teaching process (CHEN; CARSTEN, 2017). 
Many studies present the formation of humanistic values as dignity, autonomy, freedom, honesty, prosperity, equality and the development of learners' potential. People should enjoy making their own decisions about their lives, and teachers should believe that students' educational choices are well-grounded (ALONI, 2011; BROCKETT, 1998; VEUGELERS, 2011). The goal of humanistic education is to develop self-fulfilling individual (NEMIROFF, 1992). It should be considered that humanistic values develop faster when the principles of humanism are present in education. When educators have control over students, any sense of personal development and growing social justice can help others grow and be useful (DE GROOT, 2011).

Scott (1980) insists on the improvement of outcomes or achievements through humanistic learning with a special effort and shows that in a humanistic learning environment, students have a more positive attitude towards learning, spend more time on tasks, and complete them with a great pleasure (SCOTT, 1980).

We would like to point out one thing that it is necessary to use the methods of emotional activation to form humanistic values in education. In this case, humanistic values are manifested based on the resulting assessments (SEYIDOV, 2009). Humanistic values cannot be characterized only as an attitude to material objects. It is also a leading component of the spiritual world of the individual. In other words, it is the meaning of a person's life. The approach to values in this aspect requires a new methodological framework. Jabbarov (2018) shows that "values guide a person's way of life, his life strategy. Values are generalized ideas about a person's relatively important goals and behaviors. They define the priority of perception of reality, guide people's actions and deeds in all spheres of life, and significantly determine the "lifestyle" of society "(JABBAROV, 2018).

Numerous studies have been conducted on the development of humanistic values in education (WILLIIAM, 2015). The author describes four teaching methods that together form a model for the teaching of professional and humanistic values. The author defends this model by referring to the evidence and relevant literature, as well as by his extensive experience with numerous colleagues in the successful use of the model in large-scale applications. The four teaching methods are (1) teaching practical skills, (2) critical thinking, (3) a supportive group process, and (4) a basic long-term curriculum. Together, these methods create a theoretical model with mutually reinforcing elements to increase commitment to core values and optimize professional identity formation (WILLIIAM, 2015).

Humanism has never had a strong tradition in all areas of education pragmatically and in response to educational standardization, certification requirements, and industrial needs. 
However, after a period of decline, humanism has returned somewhat as part of the movement towards education in the student center. Research conducted at a technical college has shown that humanistic elements are largely absent in post-secondary technical education and are not detrimental to achieving stated educational goals (CHEN; CARSTEN, 2017).

The humanization of the system, the combination of ethics and responsibility, is an integral part of the coherent whole and is of great importance for bringing the humanities to educational leadership. In this context, both human and professional dimensions are equally important. In this way, both professional and personal life are integrated into the existence of the leader. Thus, the moral imagination clearly reveals the strategic steps of the education leader's approach to giving meaning and direction to all components of the school (BAUMEISTER, 1991).

For the formation of humanistic values, education requires the inclusion of human values in all school life, its unconditional recognition, the supremacy of ethical values integrated into the decision-making process, the normative legitimacy of actions and the solution of various problems in educational institutions. The school not only targets academic achievement, but also considers the value of human character, the existence of transparency, truth and humanistic communication with the similarity of words and actions. These components are an integral part of the spiritual imagination (EFFENDI et al., 2020).

Summarizing the research, we can conclude that the directions of the formation of humanistic values in higher education institutions are approached primarily from the perspective of the establishment of the principles of humanism in education. It is believed that the humanization of education will lead to the formation of humanistic values.

\section{Results}

The research was conducted in experimental and control groups to study the psychological characteristics of the formation of humanistic values in Azerbaijani youth. In the first stage, the values were diagnosed. The main goal here was to determine which values initially predominated in students Health is placed first with $68 \%$ among the terminal values conducted among students. In second place is a happy family life, in third place is the beauty of life. The students rated their self-confidence in the 4th place, and the presence of good and reliable friends in the 6th place. In 7th place is love and in 8th place is a materially secured life. The students rated the entertainment values in the $13^{\text {th }}$ place. The happiness of others ranks 18th. Analyzing the instrumental values among students, we can say that according to the range 
of values preferred by students, the way one is raised ranks first with $64 \%$. In the second place, students rank educational values, in the fourth place - responsibility, in the sixth place tolerance, and in the fifth place - self-control. In addition, the students noted the strong will in 8th place and the breadth of knowledge in 9th place. Values such as active life, wisdom, health, interesting work, beauty of life, love should have taken the first place legally. But here the contradiction shows itself. This situation is also reflected in instrumental values. For example, such hierarchy manifests itself in the values of neatness, politeness, high standards, vitality, performance, independence etc.

In the second stage of the research, the formative work was carried out, and then the degree of influence of individual factors on the dynamics of changes in values was studied. The results obtained in the formative work are reflected in Table 2. In the second stage, after the formative work carried out with the students, the values were re-studied, and the places occupied by the values were clarified. It should be considered that youth period is a time when they need people close to them, people with whom they can share their ideas and want to communicate. In this regard, entertainment ranks 17th place among the values of students. This shows that in the formative work, students considered it more important to focus on planned life perspectives than to move away from entertainment values.

Priority values among students include, as noted, development (first level) and social acceptance (third level). This means that they want to work on their mistakes and improve them. At the same time, the prominence of the value of social acceptance is an indicator of the changing attitude of students to humanistic values.

Table 1 - Average quantitative indicators of the relationship between age-appropriate change in values and self-realization in students

\begin{tabular}{|l|l|l|l|l|l|}
\hline Age indicators & $\begin{array}{l}\text { Terminal } \\
\text { values }\end{array}$ & $\begin{array}{l}\text { Instrumental } \\
\text { values }\end{array}$ & $\begin{array}{l}\text { Humanistic Levels of self- } \\
\text { realization }\end{array}$ & $\mathrm{N}=140$ \\
\hline $18-20$ years old & 0.35 & 0.36 & 0.28 & & Low < 32 \\
\hline 20-22 years old & 0.43 & 0.41 & 0.39 & Average 38< \\
\hline 22-25 years old & 0.46 & 0.44 & 0.42 & High 42 < \\
\hline
\end{tabular}

Source: Prepared by the authors

As can be seen in Table 1, there is a positive correlation between age level and instrumental and terminal values, including humanistic values, and the level of self-realization. The age-related dynamic change between the averages of the first 5 selected values and selfrealization is evident. This factor can be explained because students prefer humanistic values, 
including social motives, as they move on to higher courses. Additional surveys have shown that increasing the level of self-realization also plays an important role here. The appropriateness of the chosen value to the student's potential opportunities allows him or her to move away from egotistical motives or values.

As can be seen from Table 1, humanistic values manifest themselves in the relatively later years of student life. Formative work has shown that it is possible to ensure the transformation of both terminal and instrumental values into humanistic orientation values. It can be seen that students want to be accepted by other people, as well as by their peers and society, by affirming and realizing themselves.

Table 2 - Indicators of answers to the question "What values do you prefer in your life?" of students over 18 years

\begin{tabular}{|l|l|l|}
\hline Values & Boys N=65 & Girls N=75 \\
\hline Fame & 20.00 & 19.00 \\
\hline Friendship & 25.00 & 28.00 \\
\hline Material opportunity & 42.00 & 39.00 \\
\hline Justice & 13.00 & 14.00 \\
\hline
\end{tabular}

Source: Prepared by the authors

According to young people, the normalization of their socio-economic situation is a key factor for everyone to maintain one or another moral quality, moral values. Otherwise, the deformation of moral qualities can occur. This very interesting aspect shows that normal economic security, family situation, has a serious impact on the spiritual world of young people and in most cases creates conditions for their formation in society, to have a certain position, to maintain moral qualities. It can be concluded that humanistic values are conditioned on the one hand by social motives and needs, and on the other hand by individual, altruistic motives. Changing attitudes to the world can reduce or increase the importance of attitudes.

Of course, the conditions and socio-psychological environment of the Azerbaijani youth have a special role in the formation of humanistic values. As a result of the research, it became clear once again that self-awareness, self-esteem, self-actualization are important for the formation of humanistic psychological values in youth. These qualities have great impact on the development and formation of humanistic values in youth.

From this point of view, we conducted research to determine the role of self-awareness and self-esteem in the formation of humanistic psychological thinking in young boys and girls. In the research process, methodologies were used to determine the level of self-esteem in young 
boys and girls. A questionnaire survey was conducted to identify factors influencing national self-consciousness among youth.

As mentioned, 140 young students were involved in the study. The lowest age is 18 and the highest is 25 . As a result of our research, the level of self-esteem of students varies in three directions: low, medium and high.

The survey showed that $4 \%$ of students have high self-esteem, $24 \%$ have average selfesteem and $72 \%$ have low self-esteem. In particular, it was found that there is a difference between the level of self-esteem in young girls and boys. Of the $24 \%$ of average indicators $90 \%$ were boys, and of the $72 \%$ low indicators $85 \%$ were girls. Thus, the study found that young people have a low level of self-esteem. In addition, various questions were used to study the process of self-consciousness. Different criteria were used in this case. The survey found that $12 \%$ of students understand the essence of self-consciousness as self-understanding, $12 \%$ as self-knowledge. $76 \%$ could not express this concept. The expression of the essence of the concept of national self-consciousness also raised questions among young people. $7 \%$ of young people explained the essence of the concept of national self-awareness as the perception of national identity, $10 \%$ as patriotism, $6 \%$ as national moral values. $77 \%$ could not explain the concept of national self-consciousness in general. But even if young people cannot explain the essence of these concepts correctly, $50 \%$ of young people answered "yes" to the question "do you consider yourself a patriot?"

In response to the question "What is the feeling of patriotism for you?", 45\% of young people said that they love their homeland, 30\% said that they are ready for everything for the sake of homeland, $20 \%$ said that it is more important than everything and 5\% said that it is unity. In response to the question "How to be a patriotic person?", 20\% of young people said that they should protect the homeland, $30 \%$ said that they should be ready for everything for the homeland, and 50\% said that they should love the homeland. As a result of the survey, they also answered the question "Who are the national heroes for young people?" The results of the survey are shown in Figure 3. It became clear once again that national heroes, their love for the people, the land and the nation have a special role in the formation of humanistic psychology in Azerbaijani youth. As a result of the survey, the national hero ideals of young people were also identified. Analyzing all these results, it turns out that our test "Determining the level of self-esteem", the test-survey "Determining the level of national self-consciousness" showed that self-esteem among Azerbaijani youth is moderate, which has a positive impact on the formation of self-consciousness and national self-consciousness. Boys have a higher level of self-esteem than girls. However, young people with high self-esteem better explained the essence of self- 
consciousness and self-esteem. In addition, a survey was conducted to study the impact of the media on values.

Table 3 - Indicators of the correlation between humanistic values and personality traits in students

\begin{tabular}{|c|l|l|l|l|l|}
\hline $\begin{array}{c}\text { Humanistic } \\
\text { values }\end{array}$ & $\begin{array}{c}\text { Self- } \\
\text { consciousness }\end{array}$ & \multicolumn{1}{|c|}{$\begin{array}{c}\text { Cognitive } \\
\text { needs }\end{array}$} & \multicolumn{1}{|c|}{ Self-esteem } & Self-affirmation & \multicolumn{1}{c|}{$\begin{array}{c}\text { Academic } \\
\text { Needs }\end{array}$} \\
\hline Friendship & $0.32^{* *}$ & $0.35^{* *}$ & $0.20^{*}$ & 0.32 & $0.22^{*}$ \\
\hline Love & $0.89^{*}$ & $-0.37^{*}$ & $-0.76^{*}$ & $-0.26^{*}$ & 0.66 \\
\hline Empathy & $0.38^{* *}$ & -0.23 & $0.98^{*}$ & $-0.43^{*}$ & 0.54 \\
\hline Altruism & $0.58^{*}$ & 0.21 & 0.42 & 0.56 & $0.27^{*}$ \\
\hline Mental values & $0.44^{* *}$ & $0.46^{* *}$ & $0.78^{*}$ & $0.69^{*}$ & 0.19 \\
\hline Social ideals & $0.186^{*}$ & 0.232 & $0.49^{*}$ & $0.96^{*}$ & 0.72 \\
\hline
\end{tabular}

Note: It is important at the level of $* * 0.01$, at the level of $* 0.05$

Source: Prepared by the authors

As can be seen from Table 3, there is a positive correlation between humanistic qualities and personality traits and academic achievement. It is true that sometimes this trend is characteristic, but there is a positive dependence. There is an important connection between self-consciousness (at the level of $r=0,186^{*}, p<0,001$ ), self-esteem (at the level of $r=0,49^{*}$, $\mathrm{p}<0,001$ ), and self-assertion (at the level of $r=0,96^{*}, p<0,001$ ) in a social ideal that reflects humanistic qualities in students. There is a tendency dependence among other qualities. It can be concluded that in order to develop humanistic values, it is necessary to develop socially important values and personality traits. Here it is necessary to consider the cognitive needs, opportunities for self-affirmation, as well as learning achievements. As a result of the research, it became clear that the formation of humanistic thinking in young people manifests itself at certain stages. The formation of humanistic values in young people goes through the following stages.

In the third stage, it is necessary to study how the humanistic values perceived by young people affect their self-realization and spiritual development. Considering the level of selfesteem in the formation of humanistic values allows us to determine the moral position of the individual. This is reflected in the self-education of the individual.

In order to carry out the process of self-education and self-attitude in young people, it is important to study their attitude to this or that moral quality, to themselves and others, and to carry out psycho-correctional work in this direction. In particular, it is important to conduct surveys of young people in the teaching process for a certain period of time to answer their moral judgments and to organize their thinking on this topic. The formation of a moral ideal is very important for the formation of humanistic qualities in Azerbaijani youth. Also, the 
formation of a moral ideal is very important for the formation of humanistic qualities in the youth of Azerbaijan. The emergence of a positive moral ideal motivates the individual to do something useful for society. That is, it acts as a motive for a kind of personality, and in most cases leads the student to work on himself and develop himself, self-improvement, away from harmful habits. In our opinion, our ethnos psychological heritage is also important for the formation of humanistic values in students. Recommended literature is selected so that students can experience the character's situation in their own world and feel themselves in their place. Specifically, in our ethnic environment, it is possible to recommend articles, novels etc. about national heroes for the development of moral humanistic values in student youth. It is also possible to achieve the humanistic formation of student youth by quoting the lives and activities of prominent statesmen. Of course, the conditions and socio-psychological environment of the Azerbaijani youth have a special role in the formation of humanistic values.

\section{Discussion and Conclusion}

Our research has shown that it is important to create humanistic thinking in students to form humanistic values. It was found that the high potential of altruism is not due to the high level of humanistic thinking. By activating socially appreciated motivation, it is possible to realize the potential opportunities that are inherently passive and to use them effectively in the development of humanistic thinking. The results of the study showed that students have a high attitude to humanistic values, regardless of the level of self-affirmation and self-esteem. The main mechanisms of formation of humanistic values in students depend on the provocative features of social values, which occupy a dominant place in the hierarchy of values and professional self-confidence, which reflects the integrated qualities of the individual. It was found that there is a positive correlation between humanistic qualities and personal qualities and academic achievements. Sometimes although this is a trend, it is statistically significant.

\section{REFERENCES}

AZERBAIJCA FOLKLORE, (2005). Baku, Qanun.

ALONI, N. Humanistic education: From theory to practice. In: W. Veugelers (Ed.),

Education and humanism: Linking autonomy and humanity Rotterdam, Netherlands: Sense Publishers. 2011. BROCETT, R.G. Humanism as an instructional paradigm. 1998. Available: http://roghie mstr a.com/romira1.html 
DIERKSMEIER, C. What is 'Humanistic' About Humanistic Management?. Humanist Management Journal, 1, 9-32 2016; Available: https://link.springer.com/article/10$.1007 / \mathrm{s} 41463-016-0002-6$

DE GROOT, I. Why we are not democratic yet: The complexity of developing a democratic attitude. Rotterdam, Netherlands: Sense Publishers. 2011.

EFFENDI, R.; BAFADAL, I.; NYOMAN, D.; ARIFIN, I. The Construction Model of Inculcating Principal Humanistic Values in Forming a Characteristic School Environment. Preprints Posted: 2, 19, 21-43, 2020. DOI: 10.20944/preprints202011.0068.v1).

JABBAROV, R. Factors affecting the development of self-realization among students of different professions. Science and Education, 9, 75-87. 10.24195/2414-4665, 2018. Available: https://scienceandeducation.pdpu.edu.ua/en/articles/2017-9-doc/2017-9-st12-en

MASLOW, A. Motivation and personality. Moscow, Peter. 2018.

MELE, D. Understanding Humanistic Management. Humanistic Management Journal, 1(1), 33-55. 2016. DOI: 10.1007/s41463-016-0011-5

MILLER, M. D.; GREKSON, J. A. A philosophic view for seeing the past of vocational education and envisioning the future of workforce education: Ann Arbor, MI: Prakken. 1999.

NEMIROFF, G. H. Reconstructing education: Toward a pedagogy of critical humanism. New York, NY: Bergin \& Garvey. 1992.

ROKEACH, M. Beliefs, attitudes and values: a theory of organization and change. JosseyBass, San Francisco, California, USA. 1968.

PARI NAZ P.; MARYAM N.; EZATOLLAH N. Humanistic Education and students' Educational Motivation in Tehran Primary Schools. International Journal of Mental Health and Addiction, 15, 312-322. 2017. Available: https://link.springer.com/article/10.1007/s11469-016-9703-1

PENG C.; CARSTEN. S. Humanistic Elements in the Educational Practice at a United States Sub-Baccalaureate Technical College // International Journal for Research in Vocational Education and Training (IJRVET), Vol. 4, Issue 2, August 2017, 117-145. DOI: 10.13152/IJRVET.4.2.2

SCHWARTZ, S. Values: individual and cultural. Pages 463-493. In: F. J. R. van de Vijver, A. Chasiotis, and S. M. Breugelmans, editors. Fundamental questions in cross-cultural psychology. Cambridge University Press, Cambridge, UK. 2010. Available: http://dx.doi.org/10.1017/cbo9780511974090.019

SCOTT, P. Individualizing vocational education. VA: American Vocational Association. 1980.

SEYIDOV, S. I. Phenomenology of Creativity. Baku: Chashigoglu. 2009. 
SHOSTROM, E. Man-manipulator. The inner journey from manipulation to actualization. Kiev; PSYLİB. 2003.

VEUGELERS, W. A humanist perspective on moral development and citizenship education. Rotterdam, Netherlands: Sense Publishers. 2011.

WILLIIAM T. Teaching professional and humanistic values: Suggestion for a practical and theoretical model, Patient Education and Counseling, 98, 2.162-167. 2015. DOI: //doi. org/10.1 016/j.pec 2014.10.022

WADDOCK, S. Developing Humanistic Leadership Education. Humanist Management Journal, 1, 57-73, 2016. 10.1007/S41463-016-0003-5

\section{How to reference this article}

JABBARLI, M. Directions of formation of humanistic values in higher education institutions: problems and perspectives. Revista on line de Política e Gestão Educacional, Araraquara, v. 25, n. esp. 3, p. 1617-1628, Sep. 2021. e-ISSN: 1519-9029. DOI: https://doi.org/10.22633/rpge.v25iesp.3.15581

Submitted: $20 / 03 / 2021$

Required revisions: 05/06/2021

Approved: $12 / 07 / 2021$

Published: 01/08/2021 